УДК 821.161.2-1

Марія РЕУТОВА

асистент,

Донецький національний університет

імені Василя Стуса

\title{
«ДІЙСТВО ПРО ЮРІЯ-ПЕРЕМОЖЦЯ» ЮРІЯ КОСАЧА: НОМІНАТИВНИЙ АСПЕКТ АВТОРСЬКОЇ СТРАТЕГІЇ ДІАЛОГІЗМУ
}

3'ясовано, що драма «Дійство про Юрія-Переможця» відзначається тяжінням до інтертекстуальності, що $\epsilon$ інтенційним виявом авторської волі, тобто усвідомленим та спланованим прагненням письменника відмовитися від створення об'єктивної картини світу на користь витворення численних іiі версій. Обгрунтовано, що текст драми $є$ поліфонічним утворенням, чому сприяють символізація текстового поля, артикуляції номінацій, алюзій, ремінісценцій та інших маркерів діалогічності авторського мислення.

Ключові слова: інтертекстуальність, паратекстуальність, номінація, драматичний твір, алюзія, симулякр.

Прикметною особливістю сучасного літературно-художнього дискурсу є поєднання численних текстів чи їх фрагментів, сполучення непоєднуваного, іноді парадоксального, що призводить до необмеженості й непередбачуваності авторських варіацій. Кожний окремо взятий текст, як правило, виявляється місцем перетину інших, адже митець перебуває під впливом різноманітних дискурсів, реагує на інші твори. При цьому прелімінарний текст уходить у новий не у своєму оригінальному вигляді, а шляхом індивідуальної рецепції, i саме читач формує зміст твору залежно від власного світобачення. Автор має можливість скеровувати свого читача в бажаному напрямку, лишаючи йому підказки до прочитання, найпомітнішою з яких, безперечно, є назва твору. Саме тому вагомим є такий аспект інтертекстуальності, як паратекстуальність.

Аналіз українського художнього дискурсу в діахронному зрізі показує, що звернення авторів художніх творів до Біблії як джерела головної думки (концепту) свого твору на рівні заголовка безпомилково розраховане на конгеніальність українського читача 3 його картиною світу, детермінованою християнською свідомістю, яка вже стала однією 3 характерних рис 
ментальності. Заголовок драми Юрія Косача «Дійство про Юрія-Переможця» має референтно-алюзивний характер, асоціюється 3 текстом сімнадцятого сторіччя - зі «Словом про святого Юрія, лицаря Кападокійського».

Згідно 3 канонічною групою життєписів, яку відносять до середньовізантійської агіографічної традиції, св. Юрій походив із заможної родини і разом із батьком сповідував християнство. У юному віці Юрій пішов на військову службу і відзначився у війні з персами 296-297 років. За виявлену звитягу був призначений командувачем уславленої когорти Інвіктіорів, тобто «Непереможних».

Саме наприкінці III століття посилилися гоніння імператора Діоклетіана на християн. Фанатично вірячи в язичницьких богів і продовжуючи традиції культу імператорів, він таким чином уже був близьким до ідеї єдинобожжя та об’єднання державної влади із владою язичницьких жерців.

Юрій був першим із тих, хто відкрито повстав проти імператора, тому його було піддано страшним тортурам. Він стійко терпів муки, завдячуючи Господові. Коли після страшних тортур натовп побачив неушкодженого Юрія, у Христа увірувало багато присутніх, зокрема й імператриця Олександра та воєначальники Анатолій і Протолеон.

Юрій Косач залучає канонічний текст, інтерпретує його відповідно до українських подій 1677 року, зокрема відновлення гетьманування Юрія Хмельницького на Правобережній Україні. Вже на рівні заголовка інтертекстуальне підключення дає можливість авторові розставити свої акценти, запропонувати читачеві власне бачення історичних подій періоду Руїни. Головний герой твору Юрій Хмельницький також походить із християнської родини, бореться за незалежність України й має намір «відірватись від окрутнішого ци страшнішого неприятеля турчина, ніякої протекиії супостатів не взяти, тільки Бога та пресвяту Богородицю взявщи в поміч, ополчитися мужественно за солодку Отчизну, козако-сарматську Украӥну» [3, с. 176]. Як і святий Юрій, син Богдана Хмельницького до кінця не 
зрікається своєї ідеї. За авторським задумом, його мучеництво та загибель визначають перемогу ідеї. Однак, на відміну від святого Юрія, герой Ю. Косача відчуває не фізичні, а душевні страждання. Адже в передмові автор зазначає, що найважливішим для нього було відтворення «конфлікту героя з душею, себто долею» [3, с. 178].

В українському фольклорі Юрій - також воротар неба, раю, втілення справедливості. У записах П. Чубинського віднаходимо: «Та Юрай мати кличе, Та подай, матко, ключа // Одімкнути небо, випустити росу» [8, с. 342]. На думку М. Грушевського, Юрій або Юрай, Урай, Рай - це той воротар, що відмикає небо і дощ. Дослідник зауважує, що за окремими народними текстами це міг бути саме святий Юрій (Урай, Рай). Цей аспект певною мірою пов'язаний також із гетьмановою юродивістю, адже сутністю юродства $\epsilon$ психологічно загострений соціальний протест пригнобленої людини, пом'якшений хворобливою істеричністю і розумовим затьмаренням. Така форма давала можливість юродивим відносно безкарно виражати настрої стихійної непокори і народні уявлення про справедливість.

Мучеництво Юрія Хмельницького оприявнюється завдяки характеристикам, що дають йому інші персонажі драми. Так, Гальшка називає його пійманим щиголем. Сам Юрій хоче бути «залізним щицоллям» [3, с. 180]. Згідно з біблійним переказом, щиглик вирвав колючку з тернового вінця Ісуса Христа по дорозі на Голгофу, після чого чоло Спасителя почервонилося кров'ю. Найчастіше щиглик зображується в руці Немовляти - як символ християнської Душі або духовності, як знак Христа і Його страждань.

Інтертекстуальні номінації у драмі Юрія Косача надають твору підтексту. Асоціації, викликані іменем Юрій, $є$ не лише додатковим засобом характеристики героя, а й засобом типізації. Підтекст у «Дійстві про ЮріяПереможця», що виникає завдяки актуалізації власних імен, має вирішальне значення для розуміння твору. У розглянутих випадках ім'я дійової особи 
натякає на біблійну історію, а вже потім зіставлення творів розкриває духовний стан героя, його мучеництво та юродство.

Назвою драми «Дійство про Юрія-Переможця» також акцентується поетика містерійної драми. Стилізація містерійної драми $є$ свідомою орієнтацією автора, вона виконує передусім фатичну функцію інтертекстуальності, а також проявляється як конструктивна, переважно імпліцитна стратегія інтертекстуальності, що грунтується на близькості та незначному дистанціюванні текстових планів.

Юрієм Косачем уведено в заголовок лексему «дійство», характерну для містерійних творів («Дъйствіе на Страсти Христови списанное», «Дійство про Адама», «Дійство про Даніїла» тощо). Сюжетна матриця містерійної драми містить три складники: народження (пробудження) i діяння (утвердження i розквіт) - засинання (смерть) - воскресіння (переродження). Юрій Косач засвоює сюжетну матрицю великодньої містерії, але суттєво модернізує їі. Пробудження Юрія Хмельницького відбувається після визволення його 3 полону та поновлення на посаді гетьмана. Упродовж твору головний герой бореться за незалежність держави, проте, на думку автора, Юрась «почав діяти запізно і тому ворожий світ згубив його» [3, с. 200].

Як і у шкільних різдвяних містерійних драмах, у творі актуалізується символічно-алегорична постать Бога, який віщує Юрію майбутнє спасіння. У «Слові від автора» Косач дає пряму вказівку на те, що після смерті героя відбудеться відродження країни: «Мучеництвво й загибель - запорука перемоги iдеї» [3, с. 201]. У тексті драми провідником цієї ідеї постає Василь, який після загибелі головного героя пророкує, що святий Юрій «розпанахає залісну завісу» і буде «воскресення вмерлих, буде великдень, Князь-день» [3, с. 202].

В історіографії побутує думка, що Юрій Хмельницький був найбільш нещасливим 3-поміж українських гетьманів. «Він кілька разів брав до рук гетьманську булаву, але жодного разу його правління не було відзначене славетними вчинками», - відзначає Свген Луняк [5, с. 10]. Історики висувають 
ISSN 2308-1902 Актуальні проблеми української літератури і фольклору. 2017. № 25.

гіпотезу, що сходження Юрія на гетьманство було зумовлено збігом обставин, ніж його особистими амбіціями. Постать цього очільника України завжди розглядалася крізь призму величі його батька, що ще більше посилювало разючий контраст між великим Богданом і його бездарним сином.

Зазнавши невдачі в політиці, Юрій Хмельницький був змушений зректися булави та постригтися в ченці. «Ти ж знаєш, я не хотів. Від булави відрікався. I батько не хотів. А що народ? - гарбузові голови. Спокуса-народ. В монастирі було добре, легко: на віконще голуби прилітали» [3, с. 180]. Повернення гетьмана на політичну арену викликало резонанс та обурення в козацької спільноти: "Дав би, братіку, та сам пан догрався, догрався. Без інтрати. Краще б у Видубецькому поклони, братику, поклони бив, гріхи вимолював, свічки гасив» [3, с. 182].

Для розкриття проблематики твору Ю. Косач залучає номінацію із барокової літератури, зокрема 3 твору Івана Котляревського «Енеїда». «Поки Москва не викупила, по два шаги платив за них [за шаровари - М. Р.], а тепер алтини завели в Києві, то куди там Енеєві» [3, с. 205]. Номінація головного героя бурлескно-травестійної поеми допомагає реципієнту ідентифікувати проблему маргінальності українського народу. У цьому контексті слушною здається думка Віктора Неборака, який висловив упевненість у тому, що I. Котляревський витворив таку химерну модель, коли Україна шукає Україну. «Це питання про ідентичність, - зазначає В. Неборак. - Те, що нас постійно розривали в різні боки і різні політичні утворення намагаються й досі експлуатувати ці розриви» [6, с. 10]. На його думку, серйозний задум I. Котляревського полягає в тому, що він поставив питання про збирання українських земель.

Герої Косачевого твору ототожнюють себе з Енеєм. «Добрий козак був Еней, хоч гологолінник, не срібляник. Отаман таким, як оче ми, братіє, всім, хто в мандрах, хто від дому відбився, хто правди шукає» [31, с. 223]. Завдяки номінативному елементу відбувається накладання не тільки історичного 
контексту доби Руїни, а й виявляється автобіографізм Косачевого твору. Доречно порівняти історію написання «Енеїди» та «Дійства про Юрія Переможця». І. Котляревський творив свою «Енеїду» в умовах руйнування останніх залишків козацької вольності та встановлення тотального контролю над українською культурою, а найбільше літературою, коли навіть називати речі своїми іменами не дозволялося. «Дійство про Юрія-Переможця» було написано Ю. Косачем, коли українці відчували на собі політичне та національне гноблення, дискримінацію української мови, культури, перебуваючи у складі Польщі, Румунії та Чехословаччини. Комплекс меншовартості розвинувся через поразку національно-визвольних змагань в Україні 1917-1921 років і, як наслідок, встановлення радянської влади на більшій частині українських територій. Якщо «Енеїда» почала традицію завуальовування української правди з метою захистити іï від необраних, то «Дійством» Ю. Косач намагався пробудити національну свідомість українців.

Втрата свідомості акцентується Косачем зображенням пияцтва: «Не пияч, чортів сину, до стану свинячого не напивайся...» [3, с. 235]. Стан алкогольного сп’яніння пояснюється важким становищем українців у період Руїни. «Моя ияя страшна земля. Ця руїна. Але не біяйся - мор, голод, пустинь-марність. Пустиня заивіте й буятиме жизнь. Але найгірме - руїна в сериі. Найстрашніма» [3, с. 235]. Пияцтво є провідною супровідною символічною дією й подорожі Енея. У цьому контексті Ніла Зборовська наголошує: «Своєрідним маніакальним захистом від страхів постає переслідування через втечу від свідомості, тобто через несвідоме вислизання героя з буття внаслідок запаморочення свідомості» [2, с. 68]. Косач символічно пророкує прозріння у свідомості українців: «Із розуму я [тобто Юрій Хмельницький. - М. Р.] став божевільним, я юродивий, бо бачу все, бо я прозрів, а всі сліпі, бо я орел, а всі черва, бо всі раби, а я бунтар...» [3, с. 230]. Таким чином, божевілля Юрія Хмельницького символізує глибину народної саморефлексії в зародковому стані. 
Номінативні елементи можуть також виконувати текстотвірну функцію. Текстотвірна функція номінацій реалізується завдяки їх здатності впливати на текст як цілісне комунікативне утворення, а також бути одним із засобів, що сприяють встановленню цілого ряду текстових категорій. Текстотвірну функцію у драматичному творі «Дійство про Юрія-Переможця» виконує номінація «Диявол». Адже композиційним стрижнем драматичного твору постає традиційний для світового фольклору та літератури мотив угоди людини 3 Дияволом. Звернення до фаустівської проблематики стало цілком очевидним не тільки для XIX, а й, головним чином, для трагічної епохи XX століття. Легендарна структура багатопланово перегукується 3 фаустівськими аксіологічними моделями, вона грунтується на гносеологічно складному мотиві домовленості Диявола та людини, яка відважилася в реальній дійсності деміфологізувати й десакралізувати основні середньовічні християнські догми.

Можливість людини укладати угоду з Дияволом, тобто ставати на його бік у вічному протистоянні з Богом, є однією з найважливіших моральних проблем людства. Вона сягає своїм корінням давнини, а мотив «диявольського парі» зустрічається ще в фольклорі та середньовічній літературі. А. Нямцу наголошує: «Мотив договору - один з найбільш рухомих елементів традиційної структури. Зміст більшості фаустівських творів XVIII-XIX ст. визначався саме характером укладеного договору. У XX ст. він втрачає первинне значення у фаустіані й розробляється переважно в науковій фантастиці» [7]. Демонологічні легенди, які виникли в Середньовіччі, зображують звернення людини до Диявола і заборонених засобів чорної магії як про відхід від істинної віри заради тих чи інших земних поривань - багатства, честі, влади, тілесних бажань, світської мудрості; відповідно до цього вони вводять мотив договору (часто письмового) між відступником і духом зла, за яким людина, звертаючись до Диявола за допомогою, віддає йому за це свою душу.

Принципово важливою для еволюції літературної фаустіани є трагедія Й. Гете «Фауст». Подібно до багатьох інших традиційних сюжетів вона стала 
сюжетом-зразком, тобто набула статусу своєрідного абсолюту. 3 урахуванням досвіду попередніх інтерпретацій Гете відтворив у трагедії глобальну картину еволюції людських знань від античності до свого часу. Така культурологічна концентрація ускладнює сприйняття семантичних пластів твору, в якому реалістичне та символічне створюють багаторівневу змістовну єдність. Так, Фауст Гете прагне нових вражень, істини (гроші для нього мають другорядне значення, вони є не метою, а лише одним із засобів іiі досягнення). Адже у світовій літературній традиції образ «інфернального спокусника» часто асоціюється із грошима та їх згубною силою: отримані від Сатани, вони ніколи не приносять людині щастя. Так, головний герой твору «Дивна історія Петера Шлеміля» А. Шаміссо обмінює таку, здавалося б, непотрібну річ, як тінь, на «гаманець Фортуната» і згодом втрачає душевний спокій та чисте сумління. Його тезко із казки Вільгельма Гауфа віддає більше - своє серце, а 3 ним і вміння радіти життю, кохати та співчувати.

Суттєвої трансформації у Гете зазнав і мотив договору, який у більшості версій літературної фаустіани виступав провокативним каталізатором. У Юрія Косача мотив угоди з Дияволом реалізовано відповідно до гетівського. Юрій Хмельницький, як і гетівський Фауст, намагається укласти договір із Дияволом заради опанування знанням та отримання влади. У попередніх рецепціях фаустіани договір між людиною і Дияволом проголошувався гріховним вчинком, за який Фауст розплачувався вічними стражданнями душі. У Ю. Косача союз із Дияволом має характер змагання, сутність якого полягає у прагненні визначити призначення людини та іï місце в довколишньому світі. Мотив гріховності головного героя у драмі знімається повністю, пізніше він стає художньою умовністю. Хмельницький потенційно двоїстий. У діалозі 3 Юдит він висловлює зовсім протилежні міркування: «Ні, владарем будеш грімником будеш. Владу з праведністю не з'єднаєш. I Бог мене любив [...]. Бог наді мною» [3, с. 201]. Після укладання договору з Дияволом у героя з'являються зовсім інші прагнення: «Бог сахнувся від мене. I я прозрів - Бога не 
ISSN 2308-1902 Актуальні проблеми української літератури і фольклору. 2017. № 25.

треба вже мені, Юдит [...]. I я сказав: «Дияволе, прийди - поклонюся тобі» [3, с. 202]. Таким чином, підтверджується суперечливість його натури, в якій уже закладена можливість руху як вгору (до божественної істини), так і донизу (шлях до Диявола). Душа Хмельницького $є$ символом етико-релігійної дихотомії «божественне / диявольське». Факт роздвоєності дозволяє припускати два результати, які можуть бути оцінені в загальній системі цінностей як позитивний і негативний.

Трансформація традиційного мотиву угоди людини з Дияволом зазнає у драмі Ю. Косача зовсім іншої реалізації. Так, мотивація вчинків Юрія Хмельницького повністю відповідає гетівській концепції фаустіани. Провідним чинником укладання договору із князем тьми постає прагнення до пізнання як найвищого абсолюту, необхідного для успішної самореалізації як володаря. Бажання збагачення виявляється другорядним щодо духовного самовдосконалення Хмельниченка.

Мотив угоди із Дияволом накладено на фабульну матрицю середньовічної демонологічної легенди про Теофіла. Теофіл був управителем (економом) єпископа в місті Адані в Кілікії (Мала Азія), людиною великого благочестя. Після смерті єпископа він був обраний на його місце, але через смирення відмовився прийняти цей сан. Коли ж новий єпископ позбавив його посади економа, ображений Теофіл вирішив скористатися допомогою Диявола за участі чорнокнижника-єврея, адже в середні віки араби та євреї вважалися знавцями чорної магії. Диявол був викликаний чорнокнижником, і Теофіл продав йому свою душу, зрікшись християнської віри. За допомогою Диявола він повернув собі посаду і привілеї, але совість не давала йому спокою. Він вирішив покаятися. Почувши його молитви, Свята Марія вимолила йому помилування і навіть повернення підписаної ним грамоти. Теофіл присвятив решту свого життя покаянню та помер як святий.

У літературній інтерпретації демонологічної легенди жид Орун відмовляє Хмельницькому в зустрічі з Дияволом. Через це його спочатку тримають 
ув'язненим, а згодом убивають. Мету такого вчинку реципієнт дізнається тільки наприкінці твору з діалогу Юрія та Юдит: «Я твойого батька вбив, бо він тільки міг мене з Дияволом звести. Орун -мудрий жидовин. Все знав - щьо під Марсом, щчо під Скорпіоном. Я благав... Хіба для себе? Ні, я влади прагнув для тих, прийдешніх... Цю неукротиму Роксоланію, ияю Скитосарматську безодню укротити, вчинити страмного. Щоб била, як орел крильми, простори ... щуоб мій батько спав до віку ... спокійно ...» [3, с. 204]

Ім'я Орун також не є випадковим. 3 історичних джерел відомо, що приводом для усунення Хмельницького 3 політичної арени стала історія 3 єврейським крамарем Оруном, який скуповував українських дівчат для гаремів султана і потім їх вигідно продавав. За свідченням Миколи Аркаса, в 1681 році становище Юрія Хмельницького як державного діяча погіршилося: «Брак грошей та провіанту відчувався усе гостріше. Тоді Юрій знайшов «оригінальний» спосіб добування грошей, який нагадував звичайне здирництво» [1, с. 34]. Гетьман наказав сплачувати податок за одруження. «Одного разу мав оженитись син дуже заможного турецького підрядчика жида Оруна, котрого добре знали всі турецькі власті, він і не думав, що мусить теж питатись дозволу гетьмана, - пише М.Аркас. Коли почув про той непослух Хмельниченко, то вскочив в будинок i, заставши тільки жінку Оруна, звелів 3 неї живої здерти шкіру» [1, с. 34]. Внаслідок скарги Оруна до кам'янецького паші, а потім і до самого султана в 1681 році Юрія заарештували і привезли до Кам’янця-Подільського. Після нетривалого розслідування гетьмана було повішено.

Таким чином, драматург інтерпретує демонологічну легенду про Теофіла та натякає на історичний факт загибелі гетьмана. Проте історична правда у творі виконує лише функцію художнього обрамлення. На цьому тлі автор намагається відтворити природу морально-етичного конфлікту між героєм та душею, при цьому залучає чимало інших текстів. Сам Ю. Косач у передмові зазначає, що «історизм тут [тобто у драмі «Дійство про Юрія-Переможця». - 
ISSN 2308-1902 Актуальні проблеми української літератури і фольклору. 2017. № 25.

М. Р.] - виявлясться як спроба знайти надреальні енергії украӥнського минулого. Постать Юрася зосереджує їх найвиразніше. Але так само могли б ілюструвати ці вкриті енергї історії і інші постаті, $і$ то не тільки нашої минувшини», - зазначає Косач у передмові [3, с. 206]. Для автора важливим виявляється не історичний факт як такий, а трансформований через його індивідуальний психологічний досвід. Якщо у XIX столітті допускалася в художньому історичному творі наявність одночасно об'єктивності і суб’єктивності, то на початку XX ст. М. Сріблянський у статті «Літературна хвиля» наголошує: «Такого чистого усвідомленого об'єктивного погляду ніхто 3 людей не має, бо погляд може бути лише суб'єктивним, оскільки належить одній людині (навіть і тоді, коли однаковий погляд мають кілька людей) і так званий «об’єктивний погляд» вже по суті є суб'єктивним, бо належить комусь» [9, с. 27]. Історичний факт Юрій Косач перетворює на гру симулякрів, своєрідну фікцію. Якщо в античній філософії симулякр був образом речі, правда, далекої від подібності, то сучасні філософи схильні знаходити відмінності між копією та симулякром, при цьому виділяють концепт як джерело, що інспірує враження та чуттєві образи, які не зображують чогось зовнішнього, а симулюють ідею. Симулякр розглядається як образ, що позбавлений подібності з предметом, але створює ефект подібності.

Ймовірно, що Юрій Косач був ознайомлений із історіографічними працями Івана Крип'якевича, присвяченими періоду козаччини i Хмельниччини, зокрема «Матеріалами до історії української козаччини» [4], «Студіями над державою Б. Хмельницького» [4], «Богдан Хмельницький» [4]. Із них автор міг дізнатися подробиці «справи Оруна й історію про загибель Юрася в Кам'янці 1681» [4, с. 321], адже смерть головного героя драматург подає відповідно до історичної правди. «Два яничари із иілковито заслоненими обличчями йдуть до нього. На подушках вони несуть шовковий зелений шнур замморг. Юрій ще завагався, але рівно, задивлений в шнур, іде їм назустріч» [3, c. 206]. 
Відсутність історичних відомостей про життя Юрія Хмельницького зумовлює звернення драматурга до технології витворення симулякрів, що набула поширення в постмодерній поетиці. Симуляція історичного факту настільки масштабна, що вона змушує художню реальність співвідносити 3 моделями симуляції. Історичний факт у творі набуває нової легітимності, драматург звільняє реципієнта від зіставлення дубліката історії з оригіналом. Парадоксально те, що головний герой твору перетворюється з історичної особи на авторський симулякр. Його функційність визначається глибокою узагальненістю та відкритістю психологічного простору головного героя до різноманітних трансформацій. Поведінка Юрія Хмельницького зовсім не детермінована сучасними йому історичними подіями: «Коли б ми змінили костюми й перенесли дію хоч би й у сьогоднішню добу, чи змінило б це укритий глузд иієї трагедіï? Гадаю, аж ніяк» [3, с. 206]. Гетьман та історичне тло існують автономно, події періоду Руїни виконують суто декоративну функцію.

Отож, номінативні елементи у драматичному творі «Дійство про ЮріяПереможця» виявляються на рівні заголовку, проблематики та мотиву твору, постають вузлами зчеплення семантико-композиційної структури інтертексту. Номінації формують основну ідею твору, а також проявляються як асоціативні зв'язки всередині тексту, адже служать об'єднанню різних частин драматичного твору. Вони несуть функції, які визначають або доповнюють характеристику різних образів, характерів та обставин. Номінативні елементи постають одним із видів авторської рефлексії над одвічним питанням людської екзистенції в цілому і пошуками шляхів відродження української нації.

\section{ЛІТЕРАТУРА}

1. Аркас М. Історія України-Русі. Київ : Вища школа, 1993. 414 с.

2. Зборовська H. Код української літератури : проект психоісторії новітньої української літератури : монографія. К. : Академвидав, 2006. 504 с.

3. Косач Ю. Дійство про Юрія-Переможця : трагедія. Кур’єр Кривбасу. № 276-277, 2012. C. 171-226.

4. Архів Івана Крип’якевича. Папка № 164: «Бібліографія робіт І. Крип’якевича». Добірка рукописів «ІК. Плани» (аркуші 3 машинописним списком недрукованих праць 
ISSN 2308-1902 Актуальні проблеми української літератури і фольклору. 2017. № 25.

I. Крип’якевича, 1950 р. (без пагінаціі).

5. Луняк $\epsilon$. Перебування Юрія Хмельницького у турецькому полоні за свідченнями французького дипломата Де ла Круа. Січеславський альманах. № 6, 2011. С. 5-16.

6. Неборак B. В. Перечитана «Енеїда»: (Спроба сенсового прочитання «Енеїди» Івана Котляревського на тлі зіставлення з «Енеїдою» Вергілія). Львів, 2001. С. 10-13.

7. Нямиу A. Легендарно-міфологічна традиція у світовій літературі (теоретичні та історико-літературні аспекти) : Автореф. дис. ...д-ра філол. наук: 10.01.04; 10.01.05. К., Ін-т літ-ри ім. Т. Г. Шевченка НАН України, 1997. 34 с.

8. Перлини української народної пісні: упорядник Микола Гордійчук. Київ : Музична Україна, 1991. 383 с.

9. Сріблянський М. Літературна хвиля. (Погляд на літературу українську за р. 1912). Украӥнська хата. № 1, 1913. С. 27-35.

\section{REFERENCES}

1. Arkas, M. (1993). Istoriya Ukrainy-Rusi [History of Ukraine-Rus']. Kyiv: Vyshcha shkola. [In Ukrainian].

2. Zborovs'ka, N. (2006). Kod ukrainskoi literatury: proekt psykhoistorii novitnoi ukrainskoi literatury [Code of Ukrainian literature: A project of psychohistory of contemporary Ukrainian literature]. Kyiv: Akademvydav, 2006. [In Ukrainian].

3. Kosach, Yu. (2012). Diystvo pro Yuriya-Peremozhtsya : trahediya [Action about George the Victorious: a tragedy]. Kuryer Kryvbasu, 276-277, 171-226 [In Ukrainian].

4. N. a. (1950). Sheets whith machineprinted list of unpublished works by Ivan Krypyakevych. Ivan Krypyakevych's archive (Folder № 164: «Bibliohrafiya robit I. Krypyakevycha». Dobirka rukopysiv «IK. Plany»). [In Ukrainian].

5. Lunyak, Ye. (2011). Perebuvannya Yuriya Khmelnytskoho u turets'komu poloni za svidchennyamy frantsuzkoho dyplomata De la Krua [Yuriy Khmelnytskyi's stay at Turkish captivity based on witnessings of French diplomat De la Croix. Sicheslavskyi almanakh, 6, 5-16. [In Ukrainian].

6. Neborak, V. (2001). Perechytana «Eneyida»: (Sproba sensovoho prochytannya «Eneyidy» Ivana Kotlyarevskoho na tli zistavlennya z «Eneyidoyu» Verhiliya) [“Aeneida" re-read: An attempt of meaningful reading of "Aeneida" by Ivan Kotlyarevs'kyi on the background of compare to "Aeneida" by Virgil]. Lviv: (n.p.). [In Ukrainian].

7. Nyamtsu, A. (1997). Lehendarno-mifolohichna tradytsiya u svitoviy literaturi (teoretychni ta istoryko-literaturni aspekty) [Legendary and mythologic tradition in world literature (theoretical and historical literary aspects)] (Abstract of Doctor of Science Thesis). T. H. Shevchenko Institute of Literature of NAS of Ukraine, Kyiv, Ukraine. [In Ukrainian].

8. Hordiychuk, M. (Ed.). (1991). Perlyny ukrayinskoyi narodnoyi pisni [Pearls of Ukrainian folk songs]. Kyiv: Muzychna Ukrayina. [In Ukrainian].

9. Sriblyanskyi, M. (1913). Literaturna khvylya (Pohlyad na literaturu ukraiinsku za r. 1912) [Literary wave (A view upon Ukrainian literaturę for year 1912)]. Ukrainska khata, 1, 27-35 [In Ukrainian].

\section{АННОТАЦИЯ}

М. Реутова «Действие про Юрия-Победоносца» Юрия Косача: номинативный аспект авторской стратегии диалогизма»

Определено, что драма «Действие про Юрия-Победоносца» отмечается тяготением к интертекстуальности, что является интенционным проявлением авторской воли, то есть осознанным и спланированным стремлением писателя отказаться от создания объективной 
картины мира в пользу творения многочисленных ее версий. Обосновано, что текст драмы является полифоническим образованием, чему способствуют символика текстового поля, артикуляции номинаций, аллюзий, реминисценций и других маркеров диалогичности авторской речи.

Ключевые слова: интертекстуальность, паратекстуальность, номинация, драматическое произведение, алюзия, симулякр.

\section{ABSTRACT \\ Maria Reutova. "Action about George the Victorious" by Yuriy Kosach: the nominative aspect of the author's strategy of dialogism}

It was found out that the drama "Action about George the Victorious" is marked by a tendency toward intertextuality, which is an intentional manifestation of author's will, that is, consciousness and planned intention of the writer to abandon the creation of an objective picture of the world in favor of the reproduction of numerous of its versions. It is substantiated that the text of the drama is polyphonic education, which is facilitated by the symbolization of the text field, the articulation of nominations, allusions, reminiscences, and other markers of the dialogicity of copyright broadcasting.

The title of the dramatic piece appears as an explicit form of expression of the author's intertextual strategy, has a referential-illusory character and appeals to the text "The Word of St. George, the Knight of Cappadocia”. The dramatist, drawing on the canonical text, interprets it in accordance with the Ukrainian events of 1677, in particular the restoration of hetmanization of Yuri Khmelnitsky in the Right-Bank Ukraine. The title "The Struggle for Yuri-Winner" focuses on the poetry of the mysterious drama, since the writer introduces in the title the token "action" characteristic of mysterious works ("Action on the Passion of Christ written down", "The Action on Adam", "The Action on Daniil", etc.). The stylisation of the mystery drama is a purposeful author's strategy, which performs primarily a factual function of intertextuality, and also manifests itself as a constructive, predominantly implicit expression of intertextuality, based on the proximity and insignificant distances of text plans.

Key words: paratextuality, intertextuality, nomination, drama, allusion, simulacrum.

Стаття надійшла до редакційної колегії 15.10.2017 року 